\title{
Monsanto unaffected by merger halt?
}

Reversing an agreement announced last June (Nat.Biotechnol.16:612, 1998), Monsanto (St. Louis, MO) and American Home Products (AHP; Madison, NJ) decided in mid-October not to combine forces, stating that a merger was "not in the best interest of their respective shareholders." As a result, some observers say Monsanto will be freer and perhaps better able to gain its ambitious agricultural biotechnology objectives. Although Monsanto initially claimed it was unaffected by the merger impasse, the company subsequently announced a financial plan involving debt and sale of parts of the company to raise $\$ 4$ billion-capital that might otherwise have come from the merger.

Speaking before the new funding plans were announced, Gary Barton, Monsanto's director of biotechnology communications said the agricultural side of the company's business will not change in "strategy or intent" compared with the beginning of this year before there was talk of merger. "There is a perception that R\&D is turned on or off," he said, "but that's not the case." He explains that the Monsanto Life Sciences Center was established in 1984 as part of long-term projects and an investment in the future. "The company takes the long horizon on these things, and our goals continue to involve long-term commitments to biology and biotechnology in agriculture, which is fundamentally changing."

However, in order to continue towards that far horizon, Monsanto announced in November a series of financing transactions by which it plans to raise up to $\$ 4$ billion to pay for its recent seed acquisitions: This year, Monsanto has been building its agricultural business in part through the purchase of Dekalb Genetics, Delta \& Pine Land (Nat. Biotechnol. 16:497, 1998), and Cargill Seeds (Nat. Biotechnol. 16:703, 1998). This buying spree has been costly, involving an aggregate outlay of nearly $\$ 6$ billion for those three transactions. The new plan includes raising $\$ 1$ billion through the sale of parts of the business (probably involving the additional loss of around 1400 jobs) and approximately $\$ 2.5$ billion through long-term unsecured debt. The merger with AHP would have helped Monsanto in fulfilling some of its continuing capital appetites.

The loss of AHP may not have been a great one, according to some observers. Although AHP may have deeper pockets and more money than Monsanto, it "tends to sew up those pockets," says analyst Rick Stover of Arnhold \& Bleichroeder (New York). "AHP and Monsanto have very disparate cultures. AHP is very quarterly earnings driven and cost-conscious to the extreme." In contrast, he says, Monsanto has been very aggressively investing long-term in both the agricultural and pharmaceutical sides.

Monsanto currently has more than 50 new products under development in its agricultural business, and derives more than $40 \%$ of its income from agriculture-related products. "We're different from small biotech companies that are all research in that we have a strong product pipeline and established products. . .with more than 41 million acres of [genetically modified] crops planted last year," says Barton. "We intend to sustain strong financial results from our core businesses, using those funds to develop and launch new products," Robert Shapiro, Monsanto's CEO, told analysts shortly after the announcement.

Earlier this year Monsanto reported overall earnings of $\$ 470$ million from annual sales of $\$ 7.5$ billion, whereas AHP's annual sales were more than $\$ 14$ billion, with earnings of $\$ 2$ billion. In the aftermath of the abandoned merger, Monsanto's market evaluation dropped sharply from a range of \$50-60 per share to about $\$ 35$ and has since climbed gradually back into the low $\$ 40$ s. This reflected concern that Monsanto would not be able to realize its strategy in the seed market. "The ability of Monsanto to implement [its longterm] strategy on the agricultural side is more likely to happen if the company remains independent and, by going alone, it may have done better for its shareholders," says Stover, adding that "Monsanto could start seeing payoffs in the year 2000, with rapid growth thereafter."

Some of that payoff is already being realized, says analyst George Kidd, who has followed agricultural biotechnology developments for many years as a consultant in Shorewood, WI. "Monsanto is the buzz at the farm level, and a lot of their R\&D is now in commercial use," he says. Moreover, Monsanto, along with a handful of other major corporations, now holds most of the primary biotechnology-related assets needed for doing business in the agricultural sector. "There really are no small ag-biotech firms anymore," Kidd says. "They're either out of business or monopolized by the majors, with a handful of companies now holding the intellectual property, the know-how, and the people."

Despite the broken deal with AHP, Monsanto maintains that its overall agricultural biotechnology programs are holding strong. "The mood here is very upbeat," says Monsanto’s Barton.

Jeffrey L. Fox 